\title{
Giving Active Breaks and Snack Reduced Fatigue and Improved Motivation of Work and Productivity of Jaja Gipang Employee
}

\author{
Ni Luh Putu Mia Lestari Devi ${ }^{1^{*}}$, Luh Made Indah Sri Handari Adiputra ${ }^{2}$, and I Made Sutajaya ${ }^{3}$ \\ 1) Ergonomic Study Program, Postgraduate, Udayana University \\ ${ }^{2)}$ Physiology Department, Medic and Health Science Faculty, Udayana University, Denpasar \\ ${ }^{3)}$ Biology Education Study Program, Department of Marine Biology and Fisheries, Faculty of \\ Mathematics and Natural Sciences, Ganesha University of Education \\ *) Correspondence e-mail : mialestaridevi@ymail.com \\ doi: https://doi.org/10.24843/JEI.2020.v06.i02.p06
}

Article Received: 12 June 2020; Accepted: 13 October 2020 Published: 31 December 2020

\begin{abstract}
The production of jaja gipang to packaging is done manually. Jaja gipang employee do monotonous work for a long time approximately four hours of work and are accompanied by heat exposure of approximately $29.1^{\circ} \mathrm{C}$. Providing active rest and snacks in a participatory manner is very much needed. This study aims to prove and apply active resting and snacking to reduce fatigue and increase work motivation and productivity of jaja gipang employees in Sading village. This research is quasi-experimental using treatment by subject design and pre and posttest group design patterns, carried out an assessment in the form of: (a) giving active breaks and snacks to reduce fatigue jaja gipang employees measured using a 30 Items questionnaire of Rating Scale; (b) the provision of active breaks and snacks increases the work motivation of jaja gipang employees recorded with work motivation questionnaires; (c) giving active breaks and snacks increases the productivity recorded based on the output (the product produced) divided by the input (pulse) multiplied by time. Data collection was carried out before and after work in Period I and Period II of 13 samples for 10 (ten) days. The data obtained were analyzed by t-paired test at a significance level of 5\%. The results showed that giving snacks and active breaks reduced fatigue by $27.27 \%$, increased work motivation by $28.20 \%$, and increased the productivity of jaja gipang employee by $23.31 \%$. The conclusion is the provision of active breaks and snacks can reduce fatigue and increase work motivation and productivity of jaja gipang employee.
\end{abstract}

Keywords: active breaks, jaja gipang employee, snacks

\section{Pemberian Istirahat Aktif dan Kudapan Mengurangi Kelelahan dan Meningkatkan Motivasi Kerja serta Produktivitas Pembuat Gipang}

\begin{abstract}
Abstrak
Pembuatan jaja gipang dari proses produksi hingga pengemasan dilakukan secara manual. Pekerja pembuat jaja gipang melakukan pekerjaan secara monoton dalam waktu yang relatif lama kurang lebih empat jam kerja dan disertai dengan paparan panas kurang lebih $29,1^{\circ}$ C. Pemberian istirahat aktif dan kudapan secara partisipatori sangat diperlukan. Penelitian ini bertujuan untuk membuktikan dan mengaplikasikan pemberian istirahat aktif dan kudapan mengurangi kelelahan dan meningkatkan motivasi kerja serta produktivitas pembuat jaja gipang di desa Sading. Penelitian ini merupakan quasi experimental dengan model rancangan sama subjek dan pola pre and posttest group design, dilakukan penilaian berupa: (a) pemberian istirahat aktif dan kudapan mengurangi kelelahan pembuat jaja gipang diukur menggunakan kuesioner 30 Items of Rating Scale; (b) pemberian istirahat
\end{abstract}


aktif dan kudapan meningkatkan motivasi kerja pembuat jaja gipang didata dengan kuesioner motivasi kerja; (c) pemberian istirahat aktif dan kudapan meningkatkan produkivitas yang didata berdasarkan output (produk yang dihasilkan) dibagi dengan input (denyut nadi) yang dikalikan dengan time (waktu). Pendataan dilakukan sebelum dan sesudah kerja pada Periode I dan Periode II terhadap 13 sampel selama 10 (sepuluh) hari. Data yang diperoleh dianalisis dengan uji t-paired pada taraf signifikansi $5 \%$. Hasil penelitian menunjukkan bahwa pemberian kudapan dan istirahat aktif mengurangi kelelahan sebesar 27,27\%, meningkatkan motivasi kerja sebesar 28,20\%, dan meningkatkan produktivitas pembuat jaja gipang sebesar 23,31\%. Adapun simpulannya adalah pemberian istirahat aktif dan kudapan dapat mengurangi kelelahan dan meningkatkan motivasi kerja serta produktivitas pembuat jaja gipang.

Kata kunci: istirahat aktif, kudapan, pekerja jaja gipang

\section{INTRODUCTION}

Sading Village is one of the villages which is famous for its snacks making industrial village. Jaja gipang made from rice that is served without preservatives. The process of making jaja gipang is still classified as traditional, which is still using a wick stove. The ingredients used in making jaja gipang is rice, sugar, and coconut oil. Jaja gipang are packed with plastic. The manufacture of jaja gipang, from the production process to the packaging, is done manually using muscle power and is done monotonously. The production process starts at 09.00 WITA, preparing equipment such as a frying pan, stirrer, rice that has been developed, sugar, oil, sentir, plastic, ruler, and knife. The manufacturing process begins by mixing rice, oil, and sugar from 09.15 am to 09.30 am with a standing position and a bent work attitude. The mixed dough is poured into the mold for 20 minutes of grinding in a standing and bending position. The tool used to press and grind is made from pipe, then the snacks are cut to size using a ruler for 10 minutes. Ummi, et al. (2017) stated that the need for gipang cake in the community is greatly increased because it is used as a snack or snack.

Workers carry out the packaging process for a long time, from 10.00 am to $12.00 \mathrm{pm}$ with a bent work attitude while sitting down. The rest period starts from $12.00 \mathrm{pm}$ to $13.00 \mathrm{pm}$. The production process was continued until $17.00 \mathrm{pm}$. The packaging process is still done manually using a sentir, $a$ traditional lamp. The temperature at the jaja gipang production is made is a dry temperature of $29.1^{\circ} \mathrm{C}$ and a relative humidity of $64.4 \%$ and a light intensity of 210 lux. Manuaba (2015) described that the comfortable temperature for Indonesians is between $22^{\circ} \mathrm{C}$ s.d. $28^{\circ} \mathrm{C}$ and the relative humidity is between 70 to $80 \%$. The workers are not provided with drinking water, so during work the workers drinking water intake is only approximately $460 \mathrm{ml}$. This condition can cause workers to experience thirst. The dominant workers who make jaja gipang average age is 47 years. Nutrition that are not balanced in the body causes a decrease in the resistance of the human body to work, resulting in fatigue and decreased work productivity. This problem was found in workers who made jaja gipang, is the tired condition often experienced by workers after carrying out activities. The average of gipang produced by a worker in one day is 644 seeds per person. Putro and Hariyono (2017) state that fatigue is one of the problems that can be found in home industry workers.

The results of a preliminary study of 11 workers found that there were $54.55 \%$ of workers whose consumption patterns were inadequate and there was an increase in fatigue by $54.59 \%$ and an increase in work pulse by $32.30 \%$. Based on the results of a preliminary study on 11 workers, it is known that the calories consumed by workers is not in accordance with the calories for workers with a rather heavy load with the female gender it is $1,949 \mathrm{kcal}$. The workers don't get snack or food, so at $15.00 \mathrm{pm}$ the workers experience increased fatigue and decreased work motivation and productivity. The average Body Mass Index (BMI) of workers 
is $21.9 \mathrm{~kg} / \mathrm{m}^{2}$ which is still in the normal category. The wage system for workers, namely the daily work mechanism, is given Rp. 60,000. The workers do not get days off. If workers take a day off, the worker will not get paid. Participatory in ergonomics is the involvement of all workers from the beginning to the completion of an activity. Work motivation through providing active rest and snacks is needed in overcoming work fatigue. Provision of active rest, in which workers will carry out activities to take jaja gipang wrappers in the space provided and workers take snacks and drinking water available at the workplace. Based on this description, it is necessary to conduct research on how to reduce fatigue and increase work motivation and productivity through providing active rest and snacks.

\section{METHOD}

This research is a quasi-experimental study using the same subject design (treatment by subject design) and the pre and post-test group design including Period I (without intervention) and Period II (with intervention) interspersed with a washing out period for a day on Sundays to eliminate the residual effect of Period I. Furthermore, the subject was given the opportunity to adapt for a day by providing active rest and snacks. The new findings in this study are the provision of active rest and snacks. The implications of these findings on the one hand can improve the quality of jaja gipang employee health and on the other is increase productivity. The research subject was the jaja gipang employee in Sading Village, Mengwi District, Badung Regency. The population in this study were all of the gipang jaja employee in the village of Sading totalling 13 people. The samples involved in this study were 13 people with a total sampling method. The data about Fatigue was measured using 30 items of rating scale questionnaire, work motivation was measured using a work motivation questionnaire and productivity was measured using the output (product produced) divided by the input (pulse) multiplied by time. The data obtained will be analyzed, is: (a) data on the characteristics of gipang jaja employee and environmental conditions analyzed descriptively for means and standard deviations; and (b) data on fatigue, work motivation and productivity, were analyzed using t-paired test at a significance level of $5 \%$.

\section{RESULTS AND DISCUSSION}

The results of hypothesis on fatigue can be seen in Table 1 .

Table 1

Hypothesis Test Results on Fatigue in Jaja gipang Employee

\begin{tabular}{lcccccc}
\hline \multirow{2}{*}{ Variable } & \multicolumn{2}{c}{ Period I } & \multicolumn{2}{c}{ Period II } & t value & p value \\
\cline { 2 - 7 } & Mean & SD & Mean & SD & & \\
\hline $\begin{array}{l}\text { Fatigue (Before } \\
\text { Work) }\end{array}$ & 30,51 & 0,400 & 30,31 & 0,480 & 1,689 & 0,117 \\
\hline $\begin{array}{l}\text { Fatigue (After } \\
\text { Work) }\end{array}$ & 61,31 & 1,974 & 44,59 & 0,894 & 27,018 & 0,0001 \\
\hline $\begin{array}{l}\text { Fatigue } \\
\text { (deviation) }\end{array}$ & 30,79 & 2,176 & 14,28 & 0,961 & 28,729 & 0,0001 \\
\hline
\end{tabular}

The fatigue of the workers who made jaja gipang after working decreased by $27.27 \%$. Providing intervention to workers who make jaja gipang in the form of rest that is balanced with working time so that their physical capacity is more in line with the demands of the job. The characteristics of the workers who make jaja gipang work stand for 4 hours in the 
production process and sit for 4 hours in the packaging process. The workers who make jaja gipang tend to work with a static work attitude with a bent position when the packaging process is monotonous and repetitive. The application of active rest can reduce the burden due to the sitting position during the packaging process for a period of \pm 4 hours and also increase the variety of activities. Thus, active rest can increase blood flow which can affect metabolism and increase work endurance so that it can slow down the onset of fatigue. Green (2002) states that even the shortest of active breaks can reduce fatigue levels. In addition, providing snacks between work hours can reduce work boredom and consequently can reduce fatigue. Environmental conditions (temperature, light intensity, humidity, and noise) in periods I and II are comparable or have the same effect on changes in fatigue, work motivation and productivity. Snacks are given at 15.00 WITA in a participatory manner, it is by asking workers about the types of snacks and the dosage is adjusted to the average BMI of the workers. The types of snacks provided are klepon. Klepon is a snack made from rice flour or sticky rice which contains brown sugar. The nutritional of klepon is that 1 klepon has $100 \mathrm{kcal}$ consisting of $23 \%$ fat, $72 \%$ carbohydrates and $5 \%$ protein. Klepon given was 3 pieces which were in accordance with the average calorie of workers, it is $214.73 \mathrm{kcal}$. The decrease in the level of fatigue is caused by the regulation of active rest and optimization of rest periods so that the body's endurance is better maintained. The application of active rest periods is by doing walking activities to grab snacks and take plastic and water which can reduce fatigue. The reduction in fatigue is physiologically caused by the oxygen supply obtained after active rest and the nutritional intake obtained by the gipang workers.

Regarding these findings, several researchers reported that providing adequate and appropriate active rest can reduce fatigue in workers by $17.78 \%$ (Puspadewi, et al., 2018); improving working conditions through a total ergonomic approach, namely regulating work attitudes, providing short breaks, and providing tea can reduce worker fatigue from $37.77 \%$ to $35.37 \%$ (Adiatmika, 2007); giving bananas, short breaks and stretching can reduce worker fatigue in oil palm harvesters by $23.75 \%$ (Damantalm, 2018); giving snacks in the form of sweet tea and applying short breaks to odontectomy practitioners in the Department of Dentistry can reduce fatigue $52.73 \%$ to $47.00 \%$ (Wiradharma, 2012); and the application of active rest to sculptors associated with the culture that is developing in the local community, namely at Tengai Tepet or 12.00 WITA and Sandikala or 18.30 WITA may not do work and are able to improve blood circulation so that resulting in a decrease in fatigue by $11.27 \%$ (Sutajaya \& Ristiati, 2014). The results of hypothesis testing on work motivation can be seen in Table 2.

Table 2

Hypothesis Test Results on Motivation of Work in Jaja gipang Employee

\begin{tabular}{|c|c|c|c|c|c|c|}
\hline \multirow{2}{*}{ Variable } & \multicolumn{2}{|c|}{ Period I } & \multicolumn{2}{|c|}{ Period II } & \multirow{2}{*}{ t value } & \multirow{2}{*}{$\mathrm{p}$ value } \\
\hline & Mean & SD & Mean & SD & & \\
\hline $\begin{array}{l}\text { Motivation of } \\
\text { Work (Before } \\
\text { work) }\end{array}$ & 32,36 & 1,015 & 42,02 & 1,554 & 23,005 & 0,0001 \\
\hline $\begin{array}{l}\text { Motivation of } \\
\text { Work (After } \\
\text { work) }\end{array}$ & 57,29 & 2,178 & 83,97 & 4,509 & 18,941 & 0,0001 \\
\hline
\end{tabular}

The work motivation of jaja gipang employee has increased by $46.57 \%$. As for the increase in work motivation is due to the subjective impression because of the various benefits and attention obtained such as providing active rest and providing snacks. The low work 
motivation is caused by the provision of a wage (salary) of Rp. 60,000 rupiah for one work. The wage system in this industry uses a daily system. The workers are not given anything during the work process. This can be seen from the results of the questionnaire that the boss pays less attention to workers, such as never being given an award so that work motivation decreases. This results in workers just coming and working without any internal motivation to learn about their abilities. After the intervention was carried out in the form of providing active rest and snacks, the workers experienced an increase in motivation at work which was evident from the enthusiasm of the workers to make a schedule regarding taking drinking water from Beji which is located near the production process with a distance of \pm 700 meters. Initially the workers brought water from the house with a size of only $\pm 240 \mathrm{ml}$, but after an agreement was made between the researcher and the company owner regarding the importance of providing a water container, it was followed up with the provision of a drinking water container in the workplace.

Arida (2010) reports that work motivation affects worker performance. Workers who have high work motivation will use all their abilities to complete their work. Self-awareness process can be done to motivate someone. Work motivation aims to encourage workers to be able to work optimally and optimally so that it benefits the company. The individual factors that influence a person's motivation are needs, goals, attitudes, and abilities, and factors originating from the organization, namely pay, job security, fellow workers (co-workers), supervision, praise (praise), and work done by him (job itself). Related to this research, several researchers reported: (a) Theodora (2015) reported that providing active rest can increase the work motivation of PT. Sejahtera Motor Gemilang 24.35\%; (b) Manurung (2008) states that the company policy at PT. X which is related to providing snacks can increase work motivation at PT. X which includes the wage system, working days, recreation and sports, rewards. A harmonious relationship between workers and company owners so that the job can be done well. (c) Widana (2012) reported that the implementation of ergonomics in the form of active rest application and nutrition in the form of sticky rice cakes and sweet tea can increase work motivation by $12.14 \%$ in vegetable farmers in Tabanan Bali; (d) Sutajaya (2006) reports that learning through the SHIP approach can increase motivation by $48.5 \%$ of students of the Department of Biology Education, IKIP Singaraja. The results of hypothesis testing on productivity can be seen in Table 3 .

Table 3

Hypothesis Test Results on Productivity in Jaja Gipang Employee

\begin{tabular}{lcccccc}
\hline \multirow{2}{*}{ Variable } & \multicolumn{2}{c}{ Period I } & \multicolumn{2}{c}{ Period II } & \multirow{2}{*}{ t value } & p value \\
\cline { 2 - 5 } Mean & SD & Mean & SD & & \\
\hline Productivity & 19,63 & 0,613 & 27,65 & 0,717 & 33,878 & 0,0001 \\
\hline
\end{tabular}

Productivity is calculated based on the increase in the number of products produced as output and the pulse as input with in a four-hour working duration. The average productivity of jaja gipang employee in period I was 19.63 and in period II was 27.65 or an increase of $40.86 \%$. The increase in productivity by an increase of jaja gipang products that can be completed at the same time and through consideration of workloads with pulse indicators which are predominantly influenced by the increase in the results of making and packing snacks. In addition, it was caused by ergonomic interventions in the form of active resting and provision of snacks in period II. A balanced nutritional intake, together with the provision of active rest for 3 minutes, can maintain the optimal physiological condition of the gipang maker 
workers so that the body's metabolism remains normal which in turn will be able to increase work productivity.

The presence of rest arrangements seems to take up work time so it is feared that the amount of production will decrease. However, it is proven that by taking optimal rest and active rest for about 3 minutes and giving snacks, the physical and psychological condition of workers can be maintained so that the amount of production will not decrease due to fatigue and work motivation. The average amount of production has increased due to adequate rest so that workers can be better prepared and ultimately more dexterous at work. Ergonomic intervention through the application of active rest and provision of snacks is intended to create conformity between workers and task demands so that workers can create a match between workers and job demands and workers can carry out their duties safely, comfortably and productively (Sutajaya, 2018). In the first period of each worker, the average gipang produced per day was 470 jaja gipang seeds, while in the second period it increased to 579 seeds per day. In other words, the amount of production for each worker of jaja gipang maker has increased by approximately 109 seeds per day with active rest and snacks.

In relation to this research, several researchers reported that: (a) Puspadewi (2018) reported that there was an increase in productivity of $19.05 \%$ due to the application of active rest to ceramic forming workers at BTIKK BPPT Bali; (b) Ariati (2013) reports that work productivity can be influenced by various factors that play an important role in work, one of which is work nutrition. The application of ergonomics is carried out through a system, which is studied through interdisciplinary studies, and is holistic or all problems are studied thoroughly and involves participation from all parties involved. The intervention was given in the form of active rest and snacks which were given in a participatory manner and combined with the application of appropriate technology, namely: (a) economically, the cost of buying snacks (klepon) was very affordable so as not to cause harm to the company; (b) technically the implementation of active rest can be done or carried out by workers who manufacture jaja gipang; (c) in a health condition, a safe, comfortable, healthy, fit, effective and efficient condition can be created after active rest activities are carried out; (d) socially and culturally it can be mutually accepted by workers and entrepreneurs making jaja gipang; (e) energy use can be reduced; and (f) will not damage the environment. This shows that industrial owners benefit by increasing the amount of production produced by their workers.

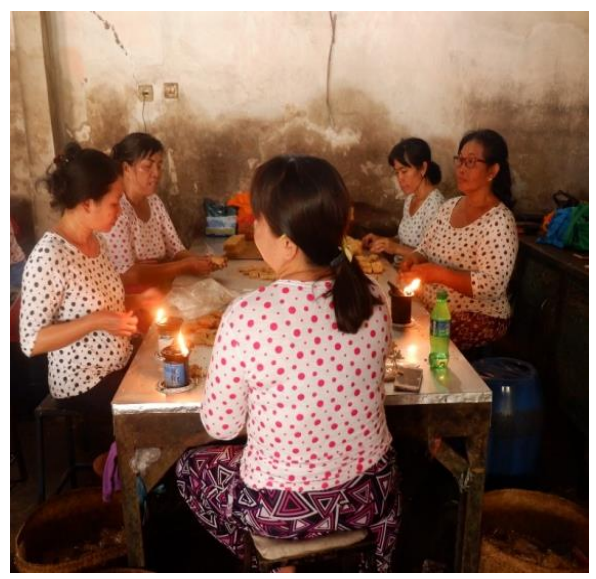

Figure 1. The worker who makes Jaja Gipang during the snack packaging process in a sitting position for 4 hours of work

Meanwhile, the expenditure for providing snacks was not too burdensome, as evidenced by the willingness and enthusiasm of the industrial owners and workers to provide snacks and look for drinking water in Beji a holy temple near the production site. The increase in profits 
during one production after being given intervention in the form of providing active rest and snacks is Rp. 401,200. With the increase in the production process produced by workers, it is hoped that the owner of the company can increase the salaries (wages) of workers so that it is expected that the welfare and work motivation of the workers who make jaja gipang workers will increase. The documentation for giving active rest and snacks is as follows at Figure 1 and Figure 2.

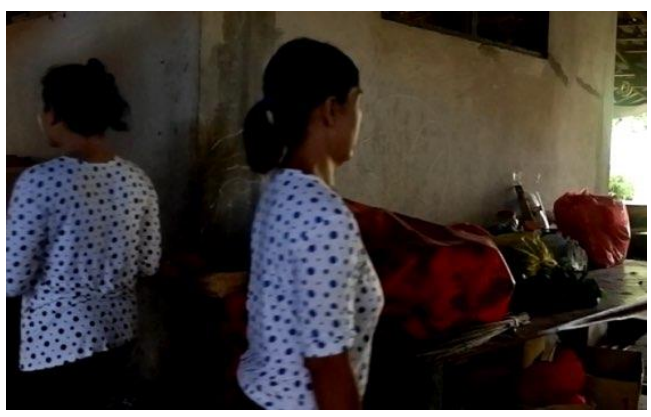

Figure 2. Workers who make Jaja Gipang take active rest by walking and taking the snacks provided

\section{CONCLUSION}

The conclusions of this study are: (a) providing active rest and snacks can reduce fatigue of jaja gipang employee by $27.27 \%$; (b) providing active rest and snacks can increase the work motivation of workers who make jaja gipang by $46.57 \%$; and (c) providing active rest and snacks can increase the productivity of the jaja gipang employee by $40.86 \%$. Suggestions that can be conveyed in this study are: (a) workers who make jaja gipang should keep doing active rest activities and pay attention to nutritional intake in the form of snacks in order to reduce fatigue and increase work motivation and productivity; (b) company managers should pay attention to active resting and snacks in order to reduce fatigue and increase motivation and productivity and not cause health problems to workers.

\section{REFERENCES}

Adiatmika, I.P.G. 2007. "Perbaikan Kondisi Kerja dengan Pendekatan Ergonomi Total Menurunkan Keluhan Muskuloskletal dan Kelelahan serta Meningkatkan Produktivitas Perajin Pengecatan Logam di Kediri Tabanan" (disertasi). Program Pascasarjana S3 Ilmu Kedokteran Universitas Udayana.

Ariati. N. N. 2013. Gizi dan Produktivitas Kerja. Jurnal Skala Husada. Vol 10(2):214-218.

Arida, A. 2010. Pengaruh Motivasi, Lingkungan Kerja dan Kepemimpinan Terhadap Kinerja Karyawan. Jurnal Administrasi Bisnis. Vol. 13(1):1-8.

Damantalm, Y., Tirtayasa, K., Adiatmika, I.P.G., Manuaba, I.B.A., Sutjana, I.D.P., and Sudiajeng, L. 2018. Pemberian Buah Pisang, Istirahat Pendek Dan Peregangan Menurunkan Keluhan Muskuloskeletal, Kelelahan Dan Meningkatkan Produktivitas Pemanen Pengguna Alat Egrek Perkebunan Kelapa Sawit PT. SSD Kalimantan Timur. Jurnal Ergonomi Indonesia. Vol. 4(1):47-56.

Gree. N. 2002. Work Related Muskuloskletal Disorder and Breaks. Journal of Industrial Medicine. Vol. 29:679-688.

Manurung, T.M.S., and Harni, B. 2008. Kajian Motivasi Kerja Dan Produktivitas Karyawan. Jurnal Ilmiah Ranggagading. Vol. 8(2):103-114. 
Puspadewi, M.A., Adiatmika, I.P.G., and Sutarja, I.N. 2018. Penerapan Istirahat Aktif Meningkatkan Kapasitas Kerja Dan Produktivitas Pekerja Bagian Pembentukan Keramik Di BTIKK BPPT Bali. Jurnal Ergonomi Indonesia. Vol.4(2):19-28.

Putro, A. N. D. R., and Hariyono, W. 2017. Beban Kerja, Status Gizi Dan Perasaan Kelelahan Kerja Pada Pekerja Industri Kerajinan Gerabah. Prosiding Seminar Nasional IKAKESMADA "Peran Tenaga Kesehatan dalam Pelaksanaan SDGs". Ed. Luciana Triana Dewi, Slamet Setio Wigati., dan Kristanto Agung Nugroho. Auditorium Kampus Bonaventura.Universitas Atma Jaya. Yogyakarta.

Sutajaya, I.M., and Ristiati, N.P. 2014. Perbaikan Kondisi Kerja Berbasis Kearifan Lokal yang Relevan dengan Konsep Ergonomi untuk Meningkatkan Kualitas Kesehatan dan Produktivitas Pematung di Desa Peliatan Ubud Gianyar. Jurnal Penelitian dan Pengembangan Sains dan Humaniora. Vol 5(3):179-186.

Sutajaya. I. M. 2016. "Pemberlajaran melalui pendekatan Sistemik, Holistik, Interdisipliner, dan Partisipatori (SHIP) Mengurangi Kelelahan, Keluhan Muskuloskletal, dan Kebosanan serta Meningkatkan Luaran Proses Belajar Mahasiswa IKIP Singaraja" (disertasi). Denpasar: Program Pascasarjana Universitas Udayana.

Theodora, O. 2015. Pengaruh Motivasi Kerja Terhadap Istirahat Aktif PT. Sejahtera Motor Gemilang. Jurnal Agora. Vol. 3(2):178-195.

Ummi, N., Akbar, and G., Ridwan, M., 2017. Identifikasi Risiko Pembuatan Kue Gipang Sebagai Makanan Tradisonal Khas Banten Dengan Metode House of Risk (HOR). Jurnal Industrial Services. Vol. 3c(1):342-350.

Widana, I.K. 2012. "Implementasi Ergonomi Pada Pengolahan Tanah Menurunkan Biaya dan Meningkatkan Produktivitas Kerja Serta Kesehatan Petani Sayur Di Tabanan Bali” (disertasi). Program Pascasarjana S3 Ilmu Kedokteran Universitas Udayana.

Wiradharma, N. 2012. "Praktikum Odontektomi Berorientasi Ergonomi Meningkatkan Kinerja Praktikan di Jurusan Kedokteran Gigi Universitas Mahasaraswati Denpasar" (thesis). Program Pascasarjana Universitas Udayana. 